\title{
Portal vein thrombosis in a patient with hepatosplenic schistosomiasis mansoni
}

Trombose da veia porta em paciente com

esquistossomose mansônica hepatoesplênica

José Roberto Lambertucci ${ }^{1}$, Vivian Resende ${ }^{2}$ and Izabela Voieta ${ }^{1}$

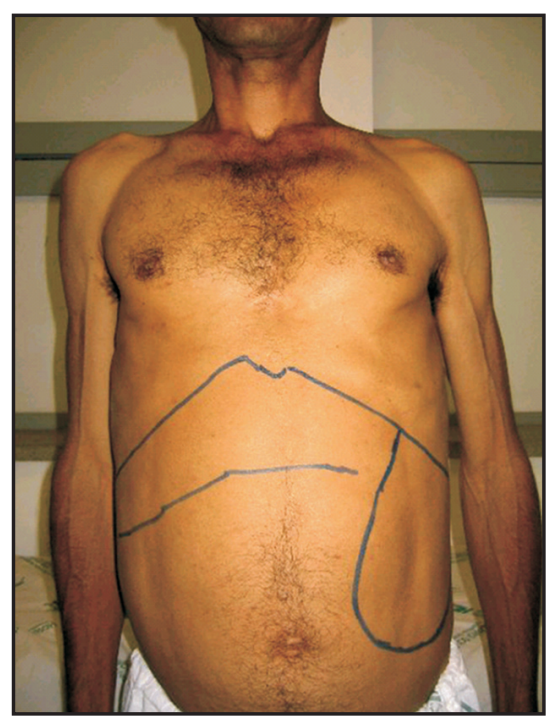

A

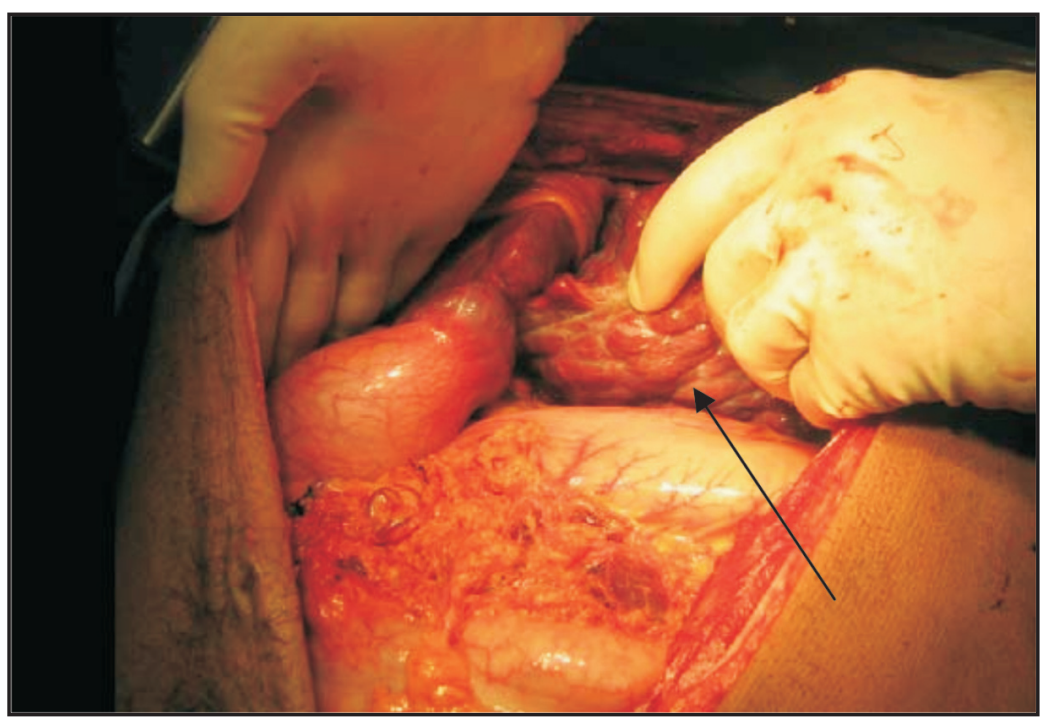

B

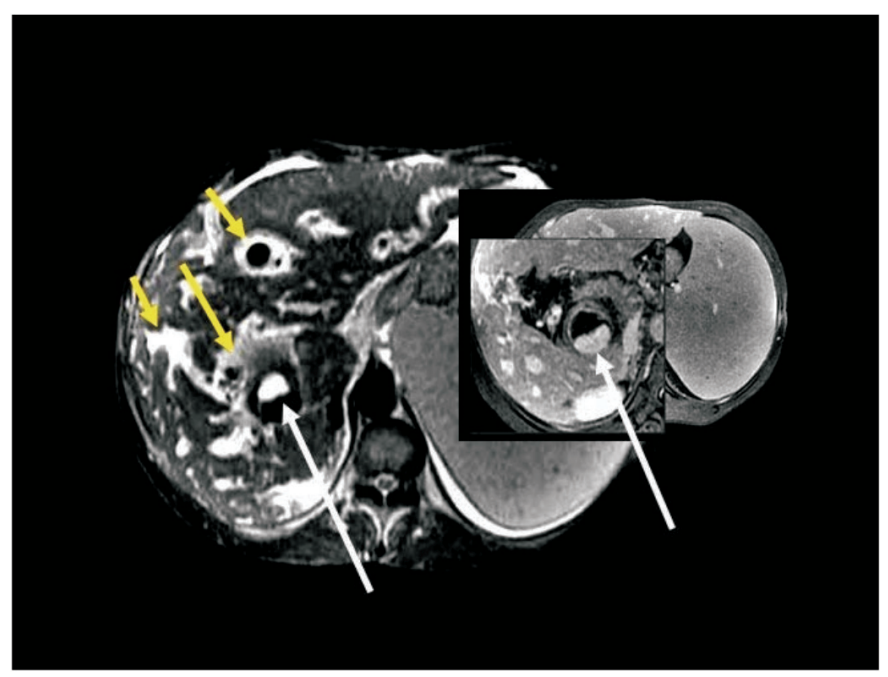

C

1. Pós-Graduação em Ciências da Saúde, Infectologia e Medicina Tropical, Faculdade de Medicina, Universidade Federal de Minas Gerais, Belo Horizonte, MG, Brasil. 2. Departamento de Cirurgia, Faculdade de Medicina da Universidade Federal de Minas Gerais, Belo Horizonte, MG, Brasil.

Address to: Dr. José Roberto Lambertucci. Faculdade de Medicina/UFMG. Avenida Alfredo Balena 190, 30130-100 Belo Horizonte, MG, Brasil.

e-mail: lamber@uai.com.br

Recebido para publicação em 11/02/2009

Aceito em 05/03/2009 
A 46-year-old male patient was admitted to hospital in October 2007 for surgical treatment of portal hypertension. He had been diagnosed with hepatosplenic Manson's schistosomiasis eight years earlier, during an episode of digestive tract bleeding. On that occasion (1999), he was treated with praziquantel and underwent repeated sessions of sclerotherapy for esophageal varices. Despite this, he presented two additional episodes of bleeding due to rupture of esophageal varices. Upon hospital admission, hepatomegaly and splenomegaly were found (Figure A). During surgery, pseudo-nodules were identified on the liver surface (Figure B - black arrow). Abdominal magnetic resonance imaging showed portal vein thrombosis (Figure $\mathrm{C}$ white arrows point to the thrombus - magnified in the inset) and periportal thickening (yellow arrows). The surgical procedure chosen was esophagogastric disconnection associated with splenectomy and suturing of the varices. Ten days after surgery, he was discharged from hospital in good clinical condition. Portal vein thrombosis is quite common (5\% of our patients) in cases of hepatosplenic Manson's schistosomiasis and is easily diagnosed by magnetic resonance imaging, before any surgical procedure.

0 paciente, de 46 anos, foi admitido ao hospital em outubro de 2007, para tratamento cirúrgico de hipertensão porta. Ele recebeu o diagnóstico de esquistossomose mansônica hepatoesplênica, oito anos antes, durante episódio de hemorragia digestiva. Na ocasião (1999), ele foi tratado com praziquantel e submetido a sessões repetidas de escleroterapia de varizes do esôfago. Apesar disso, apresentou dois novos sangramentos em decorrência de ruptura das varizes do esôfago. À admissão hospitalar, havia hepatomegalia e esplenomegalia (Figura A). Identificou-se pseudonódulos na superfície do fígado durante a cirurgia (Figura B - seta preta). A ressonância magnética do abdômen mostrou trombose da veia porta (Figura $\mathrm{C}$ - as setas brancas apontam o trombo - aumentada no destaque) e espessamento periportal (setas amarelas). A cirurgia escolhida foi desconexão esôfago-gástrica associada à esplenectomia e sutura das varizes. Dez dias após a cirurgia, ele recebeu alta hospitalar em bom estado geral. A trombose de veia porta é comum (5\% dos nossos casos) na esquistossomose mansônica hepatoesplênica e é facilmente diagnosticada pela ressonância magnética, antes de qualquer tratamento cirúrgico.

\section{REFERENCES}

1. Lambertucci JR, Andrade LM, Pinto-Silva RA. Magnetic resonance imaging of the liver in hepatosplenic schistosomiasis mansoni. Revista da Sociedade Brasileira de Medicina Tropical 35: 679-680, 2002.

2. Lambertucci JR, Serufo JC, Gerspacher-Lara R, Rayes AA, Teixeira R, Nobre V, Antunes CM. Schistosoma mansoni: assessment of morbidity before and after control. Acta Tropica 77: 101-109, 2000.

3. Petroianu A. Surgical treatment of portal hypertension in schistosomiasis mansoni. Revista da Sociedade Brasileira de Medicina Tropical 36: 253-265, 2003. 